\title{
EXPLORING THE LOCAL GRAMMAR OF EVALUATION: THE CASE OF ADJECTIVAL PATTERNS IN AMERICAN AND ITALIAN JUDICIAL DISCOURSE ${ }^{1}$
}

\author{
GianluCA PONTRANDOLFo \\ University of Trieste, Italy \\ gpontrandolfo@units.it \\ STANISLAW GoźDŹ-ROSZKOWSKI \\ University of Łódź, Poland \\ gozdz.roszkowski@gmail.com
}

\begin{abstract}
Based on a 2-million word bilingual comparable corpus of American and Italian judgments, this paper tests the applicability of a local grammar to study evaluative phraseology in judicial discourse in English and Italian. In particular, the study compares the use of two patterns: $v$-link $+A D J+$ that pattern / copula $+A D J+$ che and v-link $+A D J$ + to-infinitive pattern / copula $+A D J+$ verbo all'infinito in the disciplinary genre of criminal judgments delivered by the US Supreme Court and the Italian Corte Suprema di Cassazione. It is argued that these two patterns represent a viable and efficient diagnostic tool for retrieving instances of evaluative language and they represent an ideal starting point and a relevant unit of analysis for a cross-language analysis of evaluation in domainrestricted specialised discourse. Further, the findings provided shed light on important interactions occurring among major interactants involved in the judicial discourse.
\end{abstract}

Keywords: evaluation, judicial discourse, legal language, local grammar, pattern, phraseology

\section{Introduction}

Recent research suggests that evaluation is ubiquitous in virtually all types of communication (e.g. Hunston \& Thompson 2000, Hunston 2011, Partington et al. 2013: 44). It turns out that there are relatively few instances of linguistic interactions which would be confined to conveying only the ideational component of a message. Evaluation

\footnotetext{
${ }^{1}$ This paper stems from the ideas of both authors. However, Sections 1, 5.1.1, 5.2.1 and 6 were written by Stanislaw Goźdź-Roszkowski, whereas Sections 2, 3, 4, 5.1.2 and 5.2.2 were written by Gianluca Pontrandolfo. This contribution is based on conference papers given during the conference Meaning Context Cognition held in Łódź between 11-13 April 2013 and the $19^{\text {th }}$ European Symposium on Languages for Special Purposes, 8-10 July 2013 held at the University of Vienna.
} 
understood in its most fundamental form as "the indication that something is good or bad" (Hunston 2004:157) is arguably the driving force behind virtually all communication (Thompson \& Hunston 2000). A broader and more nuanced definition of evaluation will inevitably involve a plethora of different research perspectives and methodologies, including (without any claim to being exhaustive) appraisal (Martin and White 2005), stance (e.g. Biber 2006), metadiscourse (e.g. Hyland and Tse 2004), modality (e.g. Palmer 1987), sentiment (e.g. Taboada and Grieve 2004), evaluative, attitudinal or affective language (e.g. Ochs 1989), evidentiality (e.g. Chafe and Nichols 1986) and evaluation (e.g. Hunston 1994; 2011).

For the purpose of this study, a rather reductionist and dualistic sense of evaluation has been adopted, according to which evaluation refers to the good or bad dichotomy, disregarding other aspects such as significance, (un)certainty, (un)expectedness, etc. Evaluation is expressed through language "which indexes the act of evaluation or the act of stance-taking. It expresses an attitude towards a person, situation or other entity and is both subjective and located within a societal value system" (Hunston 1994: 210).

The present analysis is based on the premise that specialised communication occurring in domain-specific discourses is no exception to the pervasiveness of evaluation. Consequently, we examine judicial discourse, and more specifically, judgments with a view to uncovering the way(s) in which the phenomenon of evaluation is handled linguistically by the professional community of judges. Evaluation in judicial discourse remains an under researched area. The few existing studies related to evaluation in judicial discourse include e.g. Heffer 2007, who examines the linguistic construal of evaluating witnesses and defendants by trial lawyers and judges and Mazzi 2007,2010 ) who analyses the pattern 'this/these/that/those + labelling noun' in US Supreme Court Judgments (2010).

We believe that creating evaluative meanings is crucial to legal communication in judicial settings because indicating an attitude towards a legal argumentation, or process is inherent in the acts of persuasion and argumentation, which in turn appear to be an integral part of judicial discourse. Moreover, examining how evaluation is effected in comparable genres cross-linguistically should result in obtaining invaluable insights into the respective legal institutions and cultures.

This paper documents preliminary and selected findings obtained in the course of an on-going project aiming at mapping out the linguistic construal of evaluative meanings embedded in the common-law culture of the US Supreme Court Opinions and the civil law culture of the Italy's Corte Suprema di Cassazione judgments (cf. GoźdźRoszkowski \& Pontrandolfo, 2013). There is some evidence to suggest that the way evaluative meanings are created in judgments is far from being idiosyncratic or accidental. On the contrary, evaluative language tends to be highly patterned and it is argued that it could be effectively and systematically described by relying on the concept of local grammar. Consequently, the study seeks to probe the efficiency of applying a corpus-based approach to identify and quantify the pattern(s) employed to express evaluative meanings in judicial discourse. The present study is also innovative because it attempts to address the issue of evaluative meanings from a cross-linguistic perspective by examining specialist discourse across two different languages and professional cultures. One of the basic research problems encountered in comparative cross-language analysis is to determine the unit of analysis. This question seems particularly relevant in 
the case of evaluation, which is regarded as an extremely elusive and context-dependent linguistic and communicative phenomenon that can be manifested by means of widely diverse language items (see, for example, Hunston 2011).

In this paper, we adopt a corpus-based approach and draw upon the concept of a local grammar of evaluation (Hunston \& Sinclair 2000) to examine two patterns: the $v$-link + $A D J+$ that pattern and the $v$-link + ADJ + to-inf pattern. It is argued that these two patterns represent a viable and efficient diagnostic tool for retrieving instances of evaluative language in judicial language. Moreover, such patterns represent an ideal starting point and a relevant unit of analysis for a cross-language analysis of evaluation in domain-restricted specialized discourse of judicial decisions.

\section{Setting the scene: key concepts}

Before delving into the methodological issues regarding this paper, it is important to set out the conceptual boundaries of the research, focusing on what we think the key notions underpinning the project are.

As already mentioned, one of the claims made in this study is that evaluation in judgments is not expressed in a purely haphazard way. The link between specific language patterns and evaluation was established in Hunston \& Sinclair (2000), where the authors draw upon the concept of "local grammar" (Gross 1993) and "sublanguage" (Harris 1991) to find a viable analytical framework for studying evaluation. Even though it has been generally demonstrated that evaluation does not have its own grammar and it can be explored lexically, the close analysis of the items and structures involved in expressing evaluative meanings can reveal a systematic and coherent picture, hence the idea of a "local grammar of evaluation" (Hunston \& Sinclair 2000). Rather than describing a language as a whole, corpus grammarians, more specifically parsers, developed the idea that particular areas of language can be examined separately as they seem to show patterning of their own which hardly fits the generalised categories provided by general grammar.

If we look at the criteria mentioned in the literature (Lehrberger 1986, Harris 1991: 272-277, Pearson 1998, Hunston \& Sinclair 2000: 77) to assess whether a language can be regarded as satisfying the requirement of the sublanguage model, we realise that our domain (legal/judicial language), as typified in our genre (judgments), perfectly conforms to the sublanguage prototypical features:

1. Limited subject-matter

2. Lexical, syntactic and semantic restriction

3. "Deviant" rules of grammar

4. High frequency of certain constructions

5. Text structure

6. Use of special symbols

One of the overall research goals of the project is testing the applicability of a local grammar of evaluation to judicial language. The idea is that many recurrent features in our genre may fit lexico-grammatical categories which are not limited to the single text, 
but widespread across an entire genre. This paper shows some trends confirming our ideas.

From a pure methodological point of view, the present study is not framed within the computational and technical side adopted in many studies carried out by local grammarians mainly for lexicographic purposes (see the studies pioneered by Gross 1993 as Barnbrook 2002), but rather draws heavily from the theoretical considerations with a view to conducting a full-blown corpus-based study (in line with, for example, Bednarek 2007), in particular, a "corpus-assisted discourse study", borrowing Partington et al (2013)'s terminology.

In line with that strand of research which rejects the distinction between lexis and grammar - the philosophy behind the Collins COBUILD project (cf. 1992; Francis et al. 1996, 1998) - this papers adopts a pattern-grammar approach (Hunston \& Francis 2000), where the basic unit of analysis is the "pattern", understood as "all the words and structures which are regularly associated with the word and which contribute to its meaning" (Hunston \& Francis 2000: 37).

\section{Data and tools}

In order to answer the research questions we rely upon our bilingual comparable corpus of judgments (see also Goźdź-Roszkowski \& Pontrandolfo, 2013).

\begin{tabular}{|l|l|}
\hline Parameters & Bilingual (EN-IT), comparable, POS-tagged \\
\hline Type of corpus & c. 2m tokens \\
\hline Corpus size & $\begin{array}{l}\text { US subcorpus: c. 1m tokens } \\
\text { IT subcorpus: c. 1m tokens }\end{array}$ \\
\hline Subcorpora & Criminal judgments \\
\hline Genre & $\begin{array}{l}\text { US Supreme Court } \\
\text { Corte Suprema di Cassazione }\end{array}$ \\
\hline Judicial bodies & $\begin{array}{l}\text { US: 1999-2012 } \\
\text { IT: 2005-2012 }\end{array}$ \\
\hline Time span & $\begin{array}{l}\text { WordSmith Tools v. 5.0 } \\
\text { AntConc 3.2.1 }\end{array}$ \\
\hline
\end{tabular}

Table 1: Corpus for the analysis

Despite the differences between the common law and the civil law system, the Supreme Courts of both US and Italy share important roles and functions, which is the rationale behind the compilation of the corpus.

Both are the ultimate appellate courts in the respective criminal systems. The US Supreme Court rules over a limited number of cases usually involving questions about the Constitution and the federal state law, which explains the disproportion in the time span: the IT Court of Cassation (Criminal Division) is asked to deliver around 28,000 judgments per year. When it comes to the IT Court of Cassation, its duty is to ensure the correct application of the law and its uniform interpretation: it always decides on points 
of law (quaestio iuris) rather than on the quaestio facti (the "merits" of the case), dealt with by lower courts.

The corpus represents a fertile test bed for the study of evaluation. As mentioned in the introductory section, judges delivering the judgments have to employ evaluative resources to convince their audience (judges from the same or lower bench, eventual readers of the text, etc.) of what should be seen as right and proper and what not, despite the Montesquieuian idea ${ }^{2}$ that judges should be "bouche de la loi", mere translators into practices of legal norms. As pointed out by Mazzi (2010: 374), "although judges are expected to draft linear lines where the formulation of the decision merely reflects the application of the relevant legal norms to the facts of the case, the articulation of the judges' argumentation presupposes a certain degree of subjectivity". Evaluation is the engine of persuasion (Partington et al. 2013: 46) and judges have to persuade that their grounds are right or that the arguments adduced by the defendants or their counsel for defences are wrong.

The play of evaluative "voices" in judicial discourse is really complex, as we will attempt to demonstrate in the following sections.

\section{Methodology}

The present paper combines the quantitative corpus analysis with the qualitative study (close reading of the texts of our corpus), traditional to discourse studies, with the final aim of studying the interplay of evaluation not only in our corpus and discourse.

As far as the quantitative side of the analysis is concerned, we have queried our corpus in searching of the two above-mentioned patterns:

1. $v$-link $+A D J+$ that pattern / copula $+A D J+$ che

2. $v$-link $+A D J+$ to-infinitive pattern / copula $+A D J+$ verbo all'infinito

In the former case, the adjective is followed by an appositive that-clause (with our without "that") - e.g. It is true that, It is evident that / è impossibile che, è indubbio che, etc. - whereas in the latter the adjective is followed by an infinitive clause - e.g. it is difficult to see, it is necessary to decide / è necessario considerare, è opportuno intraprendere, etc.

As far as the qualitative side of the analysis is concerned, through the close reading of the co(n)texts and patterns extracted from our corpus we attempted to distinguish between evaluative and non-evaluative meanings.

The methodological steps followed for the qualitative analysis are the following ones: firstly, the patterns carrying evaluative meanings have been selected and retrieved, leaving aside the non-evaluative ones; secondly, they have been classified according to Hunston \& Sinclair (2000)'s categories and, finally, they have been interpreted in terms

\footnotetext{
2 "Les juges de la nation ne sont que la bouche qui prononce les paroles de la loi, des êtres inanimés, qui n'en peuvent modérer la force ni la rigueur" (emphasis added) (Montesquieu 1748) [Judges are no more than the mouth that pronounces the words of the law, mere passive beings, incapable of moderating either its force or rigour, 2001 [1752]: 180).
} 
of interactions between the discourse participants. Tab. 2 exemplifies the categories of analysis used for classifying the instances.

\begin{tabular}{|c|c|c|c|}
\hline $\begin{array}{c}\text { Evaluation } \\
\text { carrier }\end{array}$ & Hinge & $\begin{array}{l}\text { Evaluative } \\
\text { response }\end{array}$ & Thing evaluated \\
\hline noun group & link verb & adjective group & $\begin{array}{c}\text { that clause } \\
\text { to-infinitive clause }\end{array}$ \\
\hline $\begin{array}{l}\text { The Court } \\
\text { The Court }\end{array}$ & $\begin{array}{l}\text { is } \\
\text { is }\end{array}$ & $\begin{array}{l}\text { correct } \\
\text { wrong }\end{array}$ & $\begin{array}{l}\text { that many mental }[\ldots] \\
\text { to prohibit that }\end{array}$ \\
\hline $\begin{array}{l}\text { La Corte } \\
\text { [The Court] }\end{array}$ & $\begin{array}{l}\dot{\mathrm{E}} \\
\text { [is] } \\
\text { ha } \\
\text { ritenuto } \\
\text { [holded] }\end{array}$ & $\begin{array}{l}\text { indubbio } \\
\text { [undoubted] } \\
\text { corretto } \\
\text { [correct] }\end{array}$ & $\begin{array}{l}\text { che le indagini } \\
\text { [that investigations] } \\
\text { concedere le attenuanti } \\
\text { [to grant mitigating } \\
\text { circumstances] }\end{array}$ \\
\hline
\end{tabular}

Table 2: Descriptive categories for evaluative patterns (based on Hunston \& Sinclair 2000)

The first category refers to the subject or thing that bears someone else's evaluative comments. The hinge is the linking verb (generally, to be but also appear, become, look, seem, etc.) which connects the subject of the verb (the evaluative noun group) to additional information about that subject, that is the evaluative adjective group which realises the evaluative content. Following Hunston \& Sinclair, "these adjectives usually indicate that a particular form of behaviour is morally right or wrong, foolish or wise, and the person who carries out that behaviour is only instantially good or bad, foolish, or wise, not inherently so" (2000: 87). Finally, the that-clause or the to-infinitive clause realises the "thing evaluated", that is to say the object of the evaluation.

As we will see in the results sections, it is useful to distinguish between evaluations which are "averred", that is, affirmed by the author/speaker as his/her own, and those which are "attributed", that is, where the author/speaker assigns evaluation to other voices (Sinclair 1988 in Partington et al. 2013: 54). The instances retrieved from our corpus reveal that evaluation in judicial discourse is mostly attributed and, in many cases, the "evaluator" is an implicit one (cf. Section 5), which shed light on some dynamics and interactions between legal participants in judicial discourse.

From a mere qualitative point of view, we interpret the results in terms of positive or negative polarity.

\section{Results}

As mentioned in Section 4, the focus of this section is on two patterns typically used to express evaluation: the $v$-link $+A D J+$ that pattern (5.1) and the $v$-link $+A D J+$ toinfinitive pattern (5.2), which will be tackled both from a quantitative and qualitative perspective. 
5.1 The $v$-link + ADJ + that pattern / copula + ADJ + che

\begin{tabular}{|l|l|}
\hline \multicolumn{2}{|c|}{$v$-link $+A D J+$ that clause } \\
\hline \multicolumn{1}{|c|}{ US SC subcorpus } & \multicolumn{1}{c|}{ IT CSC subcorpus } \\
\hline Total adjectives (types): $\mathbf{4 8}$ & Total adjectives (types): $\mathbf{4 1}$ \\
\hline Total adjectives (tokens): $\mathbf{2 3 8}$ & Total adjectives (tokens): $\mathbf{2 8 7}$ \\
\hline Total evaluative adjectives (types): $\mathbf{1 9 8}$ & Total evaluative adjectives (types): $\mathbf{2 4 5}$ \\
\hline $\begin{array}{l}198 / 238=\mathbf{8 3 \%} \text { of the adjectives occurring } \\
\text { in this pattern are evaluative }\end{array}$ & $\begin{array}{l}245 / 287=\mathbf{8 5 \%} \text { of the adjectives occurring } \\
\text { in this pattern are evaluative }\end{array}$ \\
\hline
\end{tabular}

Table 3: $v$-link $+\mathrm{ADJ}+$ that pattern / copula $+\mathrm{ADJ}+$ che (quantitative results)

\begin{tabular}{|l|l|}
\hline \multicolumn{2}{|c|}{$v$-link + ADJ + that clause } \\
\hline US SC subcorpus & \multicolumn{1}{|c|}{ IT CSC subcorpus } \\
\hline clear (50) & vero [true] (43) \\
true (49) & evidente [evident] (32) \\
correct (23) & necessario [necessary] (27) \\
aware (13) & sufficiente [sufficient] (31) \\
undisputed (13) & dubbio [dubious] (13) \\
possible (12) & pacifico [obvious] (11) \\
unlikely (7) & possibile [possible] (11) \\
likely (5) & irrilevante [irrelevant] (10) \\
certain (4) & chiaro [clear] (7) \\
evident (4) & noto [lit. known] (7) \\
apparent (3) & indispensabile [indispensable] (5) \\
conceivable (3) & verosimile [plausible/likely] (4) \\
confident (3) & pensabile [lit. thinkable] (3) \\
implausible (3) & indubbio [undoubted] (3) \\
noteworthy (3) & impossibile [impossible] (3) \\
[...] & [...] \\
\hline
\end{tabular}

Table 4: $v$-link + ADJ + that pattern / copula + ADJ + che (qualitative results)

Tab. 3 shows the quantitative results of the corpus queries which confirm that the pattern under investigation is an excellent diagnostic for retrieving evaluative items. $83 \%$ of the adjectives occurring in the $v$-link $+A D J+$ that pattern are evaluative in the US subcorpus, $85 \%$ in the IT one. If we look at the qualitative results, shown in Tab. 4, we discover that there is a wide range of adjectives which can be classified according to Francis et al. (1998: 480-498)'s system of classification (cf. Goźdź-Roszkowski 2007). The most frequent adjectives refer to the validity of the theses adduced in judicial argumentation (e.g. clear, true; vero, evidente), but there are also adjectives which are used to express strong positive (e.g. undisputed, correct; indubbio, pacifico) or negative (e.g. implausible, unlikely; dubbio, irrilevante) polarity, as shown in the following sections. 


\subsubsection{Findings in the US subcorpus}

Tab. 4 above shows that an overwhelming majority of adjectives found in the $v$-link + $A D J$ that clause appear to be inherently positive, however there are a few counterexamples indicating negative evaluation. In what follows, we examine the use of two adjectives: correct and implausible to illustrate how positive and negative evaluation can be expressed in US judgments. Selected, representative examples are provided in Tab. 5 and 6 below.

\begin{tabular}{|l|l|l|l|}
\hline \multicolumn{1}{|c|}{$\begin{array}{c}\text { Entities } \\
\text { evaluated }\end{array}$} & Hinge & $\begin{array}{c}\text { Evaluative } \\
\text { category }\end{array}$ & \multicolumn{1}{c|}{ Proposition evaluated } \\
\hline Noun group & $\begin{array}{c}\text { Link } \\
\text { verb }\end{array}$ & $\begin{array}{c}\text { Adjectival } \\
\text { group }\end{array}$ & \multicolumn{1}{c|}{ that clause } \\
\hline $\begin{array}{l}\text { the Illinois } \\
\text { Coupreme }\end{array}$ & is & correct & $\begin{array}{l}\text { that General Order 92-4 is not a sufficient } \\
\text { limitation on police discretion. }\end{array}$ \\
\hline The Court & is & correct & $\begin{array}{l}\text { that many mental diseases are difficult to } \\
\text { define and the subject of great debate }\end{array}$ \\
\hline Respondent & is & correct & $\begin{array}{l}\text { that some crimes must be charged with greater } \\
\text { specificity than an indictment parroting a } \\
\text { federal criminal statute's language }\end{array}$ \\
\hline The majority & is & correct & $\begin{array}{l}\text { that rigid adherence to such an approach could } \\
\text { conceivably produce absurd results }\end{array}$ \\
\hline $\begin{array}{l}\text { Clark } \\
\text { [Petitioner] }\end{array}$ & is & correct & $\begin{array}{l}\text { that applying the moral incapacity test (telling } \\
\text { right from wrong) does not necessarily require } \\
\text { evaluation of a defendant's cognitive capacity } \\
\text { to appreciate the nature and quality of the acts } \\
\text { charged against him }\end{array}$ \\
\hline
\end{tabular}

Table 5: Examples of positive evaluation in the $v$-link + ADJ that pattern (US subcorpus)

As Tab. 5 shows, the subject positions in the clauses with correct are filled by a number of different entities representing the key interactants in the judicial appellate process: the Illinois Supreme Court as an example of a lower court (with regard to the federal US Supreme Court), the Court and majority referring basically to the prevalent opinion of the US Supreme Court judges, the Respondent and Petitoner as the two major parties to a legal dispute. All the entities are named explicitly as the target of evaluation effected by the whole range of evaluative voices occurring in the opinion part of judgments given by the US Supreme Court, namely judges expressing majority, dissenting or concurring opinions. In the examples provided above, the expression of evaluation is fairly straightforward and unequivocal. The judges, as evaluators, support the arguments put forward by the counsel representing the litigants, the lower courts or their fellow judges. However, positive evaluation of a particular point raised by a given interactant does not necessarily correspond to an overall positive evaluation of a disposition given in a particular case. For example, the sentence starting with the majority provided in Tab. 5 above comes from a dissenting opinion. The seemingly positive evaluation of an 
argument adduced in the majority opinion does not warrant that the entire argumentation and reasoning leading to a particular holding is accepted.

There is evidence (see also Section 5.2.1 below) of the phenomenon of 'embedded evaluation" . i.e. "items of intrinsically favourable evaluation which are found embedded in expressions of overall unfavourability" (Partington et al., 2013: 61-62). An inherently positive word or phrase may be embedded in a larger unit (e.g. at a sentence or paragraph level) which may be imbued with the opposite polarity.

[1] Though Clark is correct that applying the moral incapacity test (telling right from wrong) does not necessarily require evaluation of a defendant's cognitive capacity to appreciate the nature and quality of the acts charged against him, his argument fails to recognize that cognitive incapacity is itself enough to demonstrate moral incapacity, so that evidence bearing on whether the defendant knew the nature and quality of his actions is both relevant and admissible.

Excerpt [1] shows how the positive evaluation of Clark, the Petitioner (Clark is correct) found in a subordinate concessive clause, is embedded in the negative evaluation phrased in the main clause: his argument fails to recognize. This simple example signals the complexity of expressing evaluation in judicial discourse and the need for studying longer contexts beyond concordance lines.

Tab. 6 demonstrates the use of the negatively charged adjective implausible to express negative evaluation. Unlike in the case of correct, the use of implausible that entails a different variant of the $v$-link $+A D J$ that clause pattern where the that-clause is preceded by IT + link verb (the verb BE in our examples). The entity evaluated is often indicated directly in the clause following the adjective. In the examples in Tab. 6, these include the jury, this Court, and the Framers (of the American Constitution). As in the case of correct, the evaluation comes from a range of evaluative voices.

\begin{tabular}{|l|l|l|}
\hline $\begin{array}{c}\text { It link } \\
\text { verb }\end{array}$ & \multicolumn{1}{|c|}{$\begin{array}{c}\text { adjective } \\
\text { group }\end{array}$} & \multicolumn{1}{c|}{ Thing evaluated } \\
\hline It is & implausible & $\begin{array}{l}\text { that a 14-year-old's mandatory prison sentence--of any } \\
\text { length, with or without parole (...) }\end{array}$ \\
\hline It is & implausible & $\begin{array}{l}\text { that the jury supposed that past deeds pointing to a } \\
\text { constructive future could not "extenuat[e] the gravity of the } \\
\text { crime," }\end{array}$ \\
\hline It is & implausible & $\begin{array}{l}\text { that this Court could set aside entire portions of the United } \\
\text { States Code as outside Congress' power in Lopez and } \\
\text { Morrison, }\end{array}$ \\
\hline It is & implausible & $\begin{array}{l}\text { that the Framers intended to defer to legislatures as to what } \\
\text { satisfies the Public Use Clause, }\end{array}$ \\
\hline
\end{tabular}

Table 6: Examples of positive evaluation in the $v$-link + ADJ that pattern (US subcorpus)

The excerpt provided below is interesting because, while it indicates the thing evaluated, i.e. a 14-year-old mandatory sentence, the entity evaluated needs to be inferred. 
[2] It is therefore implausible that a 14-year-old's mandatory prison sentence--of any length, with or without parole--would have been viewed as cruel and unusual.

Here, the dissenting judge (Justice Alito) in Miller vs. Alabama disagrees with the ruling of his colleagues to reverse the decision of the Court of Criminal Appeals of Alabama to sentence a 14-year-old to life imprisonment without the possibility of parole. There seems little doubt that the it $v$-link $+A D J+$ that pattern is an effective diagnostic of evaluative adjectives in judicial discourse.

\subsubsection{Findings in the Italian subcorpus}

As far as the IT subcorpus is concerned, most of the patterns begin without an explicit subject - as in the case of the English introductory or anticipatory it - followed by a link verb, an adjective group, and a that or to-infinitive clause. Tab. 7 shows some examples of the pattern v-link followed by adjective group and the that-clause. As for the English subcorpus, there are cases of negative (Tab. 7) and positive (Tab. 8) polarity.

\begin{tabular}{|c|c|c|c|}
\hline $\begin{array}{c}\text { Entity } \\
\text { evaluated }\end{array}$ & Hinge & Evaluative category & Restriction on Evaluation \\
\hline Noun group & Link verb & Adjectival group & that clause \\
\hline- & - & - & - \\
\hline It link verb & $\begin{array}{l}\text { adjective } \\
\text { group }\end{array}$ & \multicolumn{2}{|c|}{ Thing evaluated } \\
\hline $\begin{array}{l}\text { E } \\
\text { [it is] }\end{array}$ & $\begin{array}{l}\text { (del tutto) } \\
\text { irrilevante } \\
\text { [(fully) } \\
\text { irrelevant] }\end{array}$ & \multicolumn{2}{|c|}{$\begin{array}{l}\text { che quegli stessi elementi si possano, teoricamente, } \\
\text { prestare ad una differente lettura } \\
\text { [that those same elements could, theoretically, be read } \\
\text { differently] }\end{array}$} \\
\hline $\begin{array}{l}\dot{\mathrm{E}} \\
\text { [it is] }\end{array}$ & $\begin{array}{l}\text { irrilevante } \\
\text { [irrelevant] }\end{array}$ & \multicolumn{2}{|c|}{$\begin{array}{l}\text { che le persone offese permangano nell'errore in cui } \\
\text { erano cadute [ai fini della sussistenza del reato di truffa] } \\
\text { [that the victims keep on repeating the same error (for } \\
\text { the definition of fraud as offence)] }\end{array}$} \\
\hline $\begin{array}{l}\dot{\mathrm{E}} \\
\text { [it is] }\end{array}$ & $\begin{array}{l}\text { irrilevante } \\
\text { [irrelevant] }\end{array}$ & \multicolumn{2}{|c|}{$\begin{array}{l}\text { che l'attività illecita potesse essere svolta anche altrove } \\
\text { ai fini della confisca } \\
\text { [that the illegal activity could have been carried out also } \\
\text { in a different place for the purposes of the confiscation] }\end{array}$} \\
\hline
\end{tabular}

Table 7: Examples of negative evaluation in the copula + ADJ che pattern (IT subcorpus)

The first example is taken from the final part of the judgment: the (implicit) evaluators are the Supreme Court judges who are dismissing the appellant's arguments. The fact that those elements could be read differently - adduced by the appellant to maintain his innocence - is absolutely irrelevant for the judges sitting at the Supreme bench. Negative evaluation is therefore expressed by means of the adjective "irrilevante", intrinsically negative per se.

The other two excerpts epitomise the function of the Italian Supreme Court judges, who are not asked to discuss the facts of the case (the "merits"), but the points of law 
and their correct interpretation and application. It is not surprising that these statements are found in the legal background's section of the judgment in which the judges have to explain the grounds of their decisions based on legal rules. In both examples, the judges are interpreting the legal definition of "offence" and "confiscation", excluding specific circumstances for being "irrelevant". The specific cases - i.e. the restrictions on evaluation, "that the victims keep on repeating the same error" and that "the illegal activity could have been carried out elsewhere" - are actually the arguments adduced by the lawyers of the appellant to defend their clients. Negativity is expressed to subtle and implicit references.

The examples in Tab. 8 show how complex is evaluation in judicial discourse. The focus is on the adjective "indubbio" (undoubted, obvious, true), having clear positive connotation.

\begin{tabular}{|c|c|c|c|}
\hline $\begin{array}{c}\text { Entity } \\
\text { evaluated }\end{array}$ & Hinge & Evaluative category & Restriction on Evaluation \\
\hline Noun group & Link verb & Adjectival group & that clause \\
\hline- & - & - & - \\
\hline It link verb & $\begin{array}{l}\text { adjective } \\
\text { group }\end{array}$ & \multicolumn{2}{|c|}{ Thing evaluated } \\
\hline $\begin{array}{l}\text { E } \\
\text { [it is] }\end{array}$ & $\begin{array}{l}\text { indubbio } \\
\text { [undoubted] }\end{array}$ & \multicolumn{2}{|c|}{$\begin{array}{l}\text { che le indagini non avessero offerto alcun elemento } \\
\text { obiettivo } \\
\text { [that the investigations did not offer any objectives } \\
\text { elements] }\end{array}$} \\
\hline $\begin{array}{l}\text { È } \\
\text { [it is] }\end{array}$ & $\begin{array}{l}\text { indubbio } \\
\text { [undoubted] }\end{array}$ & \multicolumn{2}{|c|}{$\begin{array}{l}\text { che il percorso argomentativo del decidente è infondato } \\
\text { e illogico } \\
\text { [that the argumentative path adopted by the judge [lit. } \\
\text { decider] is groundless and illogical] }\end{array}$} \\
\hline $\begin{array}{l}\dot{\mathrm{E}} \\
\text { [it is] }\end{array}$ & $\begin{array}{l}\text { indubbio } \\
\text { [undoubted] }\end{array}$ & \multicolumn{2}{|c|}{$\begin{array}{l}\text { che }[\ldots] \text { fornisce un ulteriore tassello all'impianto } \\
\text { accusatorio } \\
{[\text { that }[\ldots] \text { represents a further 'piece' to the accusation }} \\
\text { framework] }\end{array}$} \\
\hline
\end{tabular}

Table 8: Examples of negative evaluation in the copula + ADJ che pattern (IT subcorpus)

The evaluator of the first two examples is the appellant - by means of his lawyer - who is contesting the decision of the lower-court judges who found him guilty: no doubts that the investigations did not offer any objective elements and that the grounds of the judges who decided the case are illogical. A positive adjective, which usually displays a favourable evaluative priming, is embedded in negative contexts (cf. Partington et al. 2013: 61-63).

However, in the following example, the evaluator changes: the Supreme Court judges are backing the decision of their colleagues from the lower-court bench who found the appellant guilty.

[3] Se, però, la suddetta dichiarazione viene letta, come si deve, insieme a tutte le altre, è indubbio che, come hanno rilevato entrambi i giudici di merito, fornisce un ulteriore 
tassello allimpianto accusatorio perché è una dichiarazione che, ancora una volta, individua il L.G. come un soggetto orbitante nell'ambito dell'associazione mafiosa [...]

[If, however, such statement is read, as it should be, together with the other ones, it is undoubted that, as both lower-court judges have noted, it represents a further 'piece' to the accusation framework since it is a statement that, once again, considers L.G. as a subject moving around the area of mafia-type associations [...]

Again, a positive adjective is embedded in a context of negative evaluation (the accusation of the appellant). The notion of "trueness" is of course subject to subjectivity, especially in the dialectics of the parties that play a pivotal role in our genre.

\subsection{The $v$-link + ADJ + to-inf pattern / copula $+A D J+v$-inf}

\begin{tabular}{|l|l|}
\hline \multicolumn{2}{|c|}{$v$-link $+A D J+$ that clause } \\
\hline US SC subcorpus & IT CSC subcorpus \\
\hline Total adjectives (types): 61 & Total adjectives (types): $\mathbf{4 1}$ \\
\hline Total adjectives (tokens): 662 & Total adjectives (tokens): $\mathbf{2 4 1}$ \\
\hline Total evaluative adjectives (types): $\mathbf{5 2 5}$ & Total evaluative adjectives (types): $\mathbf{2 2 3}$ \\
\hline $\begin{array}{l}525 / 662=\mathbf{7 9 \%} \text { of the adjectives } \\
\text { occurring in this pattern are evaluative }\end{array}$ & $\begin{array}{l}223 / 241=\mathbf{9 2 \%} \text { of the adjectives } \\
\text { occurring in this pattern are evaluative }\end{array}$ \\
\hline
\end{tabular}

Table 9: $v$-link + ADJ + to-inf pattern / copula $+\mathrm{ADJ}+v$-inf (quantitative results)

\begin{tabular}{|l|l|}
\hline \multicolumn{2}{|c|}{$v$-link + ADJ + to-inf clause } \\
\hline US SC subcorpus & \multicolumn{1}{|c|}{ IT CSC subcorpus } \\
\hline likely (70) & possibile [possible] (52) \\
necessary (52) & necessario [necessary] (34) \\
difficult (45) & sufficiente [sufficient] (24) \\
sufficient (43) & opportuno [convenient/appropriate] (19) \\
unable (41) & agevole [easy] (16) \\
insufficient (29) & illogico [illogical] (11) \\
hard (27) & impossibile [impossible] (7) \\
correct (23) & equo [fair] (6) \\
unlikely (18) & difficile [difficult] (5) \\
willing (16) & utile [useful] (5) \\
important (16) & irrilevante [irrelevant] (4) \\
appropriate (16) & inutile [useless] (4) \\
wrong (14) & indispensabile [indispensable] (3) \\
reluctant (13) & decisivo [crucial] (3) \\
impossible (10) & facile [easy] (2) \\
[...] & {$[\ldots]$} \\
\hline
\end{tabular}

Table 10: $v$-link + ADJ + to-inf pattern / copula + ADJ + v-inf (qualitative results) 
The quantitative and qualitative results of the corpus queries confirm that also this pattern is highly evaluative. In particular, $79 \%$ of the adjectives occurring in the $v$-link + $A D J+$ to-inf pattern are evaluative in the US subcorpus, $92 \%$ in the IT one. The quantitative results are similar to those obtained in the previous pattern (cf. Tab. 3 in 5.1 ), with the exception of the higher frequency of adjectives conveying necessity or importance (e.g. necessary, important; necessario, opportuno). The following sections contextualise a selected number of adjectives used with positive or negative polarity.

\subsubsection{Findings in the US subcorpus}

\begin{tabular}{|l|l|l|l|}
\hline \multicolumn{1}{|c|}{$\begin{array}{c}\text { Entity } \\
\text { evaluated }\end{array}$} & \multicolumn{1}{c|}{ Hinge } & \multicolumn{1}{c|}{ Evaluative category } & \multicolumn{1}{c|}{ Proposition evaluated } \\
\hline Noun group & Link verb & \multicolumn{1}{c|}{ Adjectival group } & \multicolumn{1}{c|}{ to-infinitive clause } \\
\hline $\begin{array}{l}\text { The Sixth } \\
\text { Circuit } \\
\begin{array}{l}\text { The majority } \\
\text { The Court } \\
\text { The dissent }\end{array}\end{array}$ & $\begin{array}{l}\text { was } \\
\text { is } \\
\text { is }\end{array}$ & $\begin{array}{l}\text { wrong } \\
\text { wrong } \\
\text { wrong } \\
\text { wrong }\end{array}$ & $\begin{array}{l}\text { to hold that } \\
\text { to say that } \\
\text { to suggest } \\
\text { to read }\end{array}$ \\
\hline It link verb & $\begin{array}{l}\text { adjective } \\
\text { group }\end{array}$ & \multicolumn{2}{|c}{ Thing evaluated } \\
\hline It is & quite wrong & to invite state court judges to discount... \\
\hline It is & wrong & $\begin{array}{l}\text { to assume that his petition by itself failed to alert the } \\
\text { Oregon Supreme Court to the federal nature of }\end{array}$ \\
\hline
\end{tabular}

Table 11: Examples of negative evaluation in the $v$-link + ADJ + to-inf pattern (US subcorpus)

Tab. 11 illustrates how the pattern $v$-link followed by adjective group and the toinfinitive clause contains instances of negative evaluation directed at a range of interactants appearing in the judicial discourse. As can be seen, the pattern $v$-link $+A D J$ + to-inf clause pattern can be realized as two variants. The first one, shown in the upper part of Tab. 2, identifies explicitly a legal interactant as a subject of the main clause and the target of evaluation. The noun group slot can be filled in by a range of entities including a lower court (the Sixth Circuit), a majority opinion of the US SC (referred to as the Court), a dissenting judge or judges, and a respondent. The other variant shown in the lower part of Tab. 11, consists of it v-link followed by to-inf clause.

[4] The Sixth Circuit was also wrong to hold that prosecutorial inconsistencies between the Stumpf and Wesley cases required voiding Stumpf 's guilty plea.

Example [4] comes from the holding of the Bradshaw, Warden vs. Stumpf judgment in which the Supreme Court unanimously rejected the decision by the United States Court of Appeals for the Sixth Circuit to reverse an earlier judgment given by a District Court. In this case, there is a negative evaluation of the lower court's, i.e. the Sixth Court's judicial action which correlates with the Supreme Court overall negative decision encapsulated in its disposition: "reversed in part, vacated in part and remanded". Negative evaluation can also be averred by judges sitting on the same bench. 
Importantly, a Supreme Court judge can write a dissenting opinion in which he or she is joined by other judges. Predictably, such opinion is replete with negative evaluation of argumentation put forward by the majority of judges. A good illustration is provided in [5]:

[5] The majority is also wrong to say that this Court has "narrowed" Parden in its "subsequent opinion[s]," ante, at 12, at least in any way relevant to today's decision.

In [5] the dissenting judge Justice Breyer (Expense Board et al. on writ of certiorari to the United States Court of Appeals for the Third Circuit) finds a perceived flaw in the argumentation expounded in the majority opinion. Although a dissenting opinion has no bearing on the disposition, it provides an extremely useful insight into legal reasoning. Examples [4] and [5] represent an explicit averral of evaluation by means of the variant noun group $+v$-link + adjective + to-inf clause. In contrast, the it v-link + to-inf clause variant is used as more covert form of expressing evaluation. Example [6], provided below, is a case in point.

[6] It is quite wrong to invite state court judges to discount the importance of such guidance on the ground that it may not have been strictly necessary as an explanation of the Court's specific holding in the case.

In the above excerpt [6] from Thomas L. Carey, Warden, Petitioner V.Mathew Musladin, Justice Stevens concurs in the judgment albeit with serious reservations. While it is easy to identify the judge as the evaluator, the same does not apply to the entity evaluated. The preceding context suggests that the evaluation is directed at the Ninth Circuit by pointing out the consequences of its decision and the impact this decision may have had on state court judges. At the same time, the evaluation also implicates the Supreme Court by referring to its past holdings.

The pattern $v$-link $+A D J+$ to-inf clause can also contain positive evaluation. This is illustrated by looking at the adjective adequate in Tab. 12. If we compare Tab. 11 and 12 , it becomes immediately clear that apart from a change in polarity, i.e. from negative to positive, there is also a change in the type of subjects of the main clause and their relationship with the to-inf. clauses. For one, subject positions for the clauses with adequate are filled by non-animate concrete objects denoting specific legal documents, such as terms of the Force Resolution, the record of a plea proceeding, the summary judgment evidence. Second, the verbs found in to-infinitive clauses are different. Tab. 11 shows that the adjective wrong is used with verbs belonging to the semantic category of communication, e.g. say, suggest, hold, etc. There seems to be a relationship of a close proximity between the subject of the main clause and the verb in the to-infinitive clause, i.e. a given interactant (e.g. court) is directly responsible for a particular act of 'holding' or 'suggesting'. In contrast, Tab. 12 shows instances of positive evaluation where the concrete nouns acting as subjects of a clause cannot be held accountable for the actions indicated by the verbs in the to-infinitive clause. 


\begin{tabular}{|c|c|c|c|}
\hline Entity evaluated & Hinge & $\begin{array}{l}\text { Evaluative } \\
\text { category }\end{array}$ & Restriction on evaluation \\
\hline Noun group & $\begin{array}{l}\text { Link } \\
\text { verb }\end{array}$ & $\begin{array}{l}\text { Adjectival } \\
\text { group }\end{array}$ & to-infinitive clause \\
\hline the issues presented & are & adequate & $\begin{array}{l}\text { to deserve encouragement to } \\
\text { proceed further }\end{array}$ \\
\hline $\begin{array}{l}\text { (...) the terms of the } \\
\text { Force Resolution }\end{array}$ & are & adequate & $\begin{array}{l}\text { to authorize detention of an } \\
\text { enemy combatant }\end{array}$ \\
\hline $\begin{array}{l}\text { the record of a plea } \\
\text { proceeding }\end{array}$ & is & fully adequate & $\begin{array}{l}\text { to enable discretionary review } \\
\text { and, }\end{array}$ \\
\hline $\begin{array}{l}\text { the summary judgment } \\
\text { evidence }\end{array}$ & is & at least adequate & to entitle MGM to go forward \\
\hline
\end{tabular}

Table 12: Examples of positive evaluation in the $v$-link + ADJ + to-inf pattern (US subcorpus)

For example, it can be argued that the terms of the Force Resolution are evaluated positively as having the necessary quality of adequacy which makes is possible for a different duly authorized entity to detain an enemy combatant. In other words, it is not the subject of this clause that will be directly involved in authorizing the detention. The legal instrument serves as a mere basis for the subsequent action:

[7] Next, there is the Government's claim, accepted by the Court, that the terms of the Force Resolution are adequate to authorize detention of an enemy combatant under the circumstances described, [a claim the Government fails to support sufficiently to satisfy $\S 4001$ (a) as read to require a clear statement of authority to detain]

Importantly, excerpt [7] provides an example of the phenomenon of embedded evaluation, and it shows that interplay of evaluative voices can be indeed quite complex, especially in the case of attributed evaluation. The adjective adequate is intrinsically positive and as such is used to evaluate the terms of the Force Resolution. It should be noted that this instance of positive evaluation is attributed to the Government by the author of this opinion (Justice Souter concurring in the judgment of Yaser Esam Hamdi and Esam Fouad Hamdi, as Next Friend of Yaser Esam Hamdi, Petitioners V. Donald H. Rumsfeld, Secretary Of Defense, et al.). The positive evaluation is embedded in the wider context (marked in Example 4 in square brackets) of negative evaluation - a claim the Government fails to support - unequivocally signalled in the opinion. Interestingly, it turns out that the seemingly positive evaluation of a legal instrument relied upon by one interactant (the Government) can be in fact used against this interactant.

It appears that positive evaluation of a legal document can also be used in much less explicit terms as in Example [8]:

[8] Furthermore, as I have explained, the record of a plea proceeding is fully adequate to enable discretionary review and, in turn, to permit the correction of errors in the factfinding process when necessary.

This excerpt comes from a dissenting opinion of Justice Thomas in Antonio Dwayne Halbert, Petitioner v. Michigan. There is a positive evaluation of the quality of the 
record of a plea proceeding as meeting the requirements to carry out a review leading to the correction of errors found in the fact-finding process. Unlike in [7], there is a single evaluative voice without a clear indication of any legal interactant involved in this case.

\subsubsection{Findings in the IT subcorpus}

The v-link $+A D J+$ to-infinitive pattern shows similar results in term of evaluative polarity. Adjectives are used in contexts characterised by both polarities and the interplay between judicial voices retain its complexity.

\begin{tabular}{|c|c|c|c|}
\hline $\begin{array}{c}\text { Entity } \\
\text { evaluated }\end{array}$ & Hinge & Evaluative category & Restriction on Evaluation \\
\hline Noun group & Link verb & Adjectival group & to-infinitive clause \\
\hline- & - & - & - \\
\hline $\begin{array}{c}\text { It link } \\
\text { verb }\end{array}$ & $\begin{array}{l}\text { adjective } \\
\text { group }\end{array}$ & \multicolumn{2}{|c|}{ Thing evaluated } \\
\hline $\begin{array}{l}\dot{\mathrm{E}} \\
\text { [it is] }\end{array}$ & $\begin{array}{l}\text { (certamente) } \\
\text { illogico } \\
\text { [(certainly) } \\
\text { illogical] }\end{array}$ & \multicolumn{2}{|c|}{$\begin{array}{l}\text { collegare l'omicidio alla lite in cui quello stesso } \\
\text { pomeriggio rimasero coinvolti la vittima ed il T.. } \\
\text { [to link the murder to the quarrel occurred the same } \\
\text { afternoon between the victim and T.] }\end{array}$} \\
\hline $\begin{array}{l}\text { Sarebbe } \\
\text { [it would] }\end{array}$ & $\begin{array}{l}\text { illogico } \\
\text { [illogical] }\end{array}$ & \multicolumn{2}{|c|}{$\begin{array}{l}\text { individuare il movente della azione omicidiaria nella } \\
\text { necessità di vendicare l'attentato subito da P.F. } \\
\text { [to identify the motive for the crime with the need to } \\
\text { avenge the offence suffered by P.F.] }\end{array}$} \\
\hline $\begin{array}{l}\text { Era } \\
\text { [it was] }\end{array}$ & $\begin{array}{l}\text { illogico } \\
\text { [illogical] }\end{array}$ & \multicolumn{2}{|c|}{$\begin{array}{l}\text { sostenere da parte dei giudici di merito che le "false" } \\
\text { dichiarazioni dell' A.N. erano di fatto inutilizzabili ai fini } \\
\text { della ricostruzione dell'omicidio } \\
\text { [for the lower-court judges to maintain that the 'false' } \\
\text { statements made by A.N. were actually not usable for } \\
\text { the purposes of the murder's reconstruction] }\end{array}$} \\
\hline
\end{tabular}

Table 13: Examples of negative evaluation in the copula + ADJ $+v$-inf pattern (IT subcorpus)

The excerpts show cases of negative polarity expressed by an introductory it-link verb, followed by an intrinsically negative adjective ("illogico", illogical), and by an infinitive clause.

The evaluator of the three examples is the appellant, by means of his lawyer, who is contesting the decision of the lower-court judges who found him guilty. The grounds adduced by the judges are illogical, according to them: there is no correlation between the murder and the quarrel in the first example, nor between motive for the crime and revenge in the second example. Illogical is also the interpretation of the lower-court judges in the latest example. Negativity is also stressed by the use of the inverted commas (quotation mark) in 'false' which expresses a strong disagreement between the accusation and the defence: according to the appellant's lawyer the declarations of his client are obviously not 'false'. 
Tab. 14 exemplifies cases of positive polarity in the $v$-link $+A D J+$ to-inf pattern.

\begin{tabular}{|l|l|l|l|}
\hline \multicolumn{1}{|c|}{$\begin{array}{c}\text { Entity } \\
\text { evaluated }\end{array}$} & \multicolumn{1}{|c|}{ Hinge } & \multicolumn{1}{c|}{$\begin{array}{c}\text { Evaluative } \\
\text { category }\end{array}$} & \multicolumn{1}{c|}{ Restriction on Evaluation } \\
\hline Noun group & \multicolumn{1}{|c|}{ Link verb } & $\begin{array}{c}\text { Adjectival } \\
\text { group }\end{array}$ & \multicolumn{1}{c|}{ to-infinitive clause } \\
\hline $\begin{array}{l}\text { La Corte } \\
\text { [The Court] }\end{array}$ & $\begin{array}{l}\text { ha ritenuto che } \\
\text { fosse stata [sic] } \\
\text { [believed it was] }\end{array}$ & $\begin{array}{l}\text { corretto } \\
\text { [correct] }\end{array}$ & $\begin{array}{l}\text { concedere le attenuanti generiche } \\
\text { solo equivalenti } \\
\text { [to grant exclusively the equivalent } \\
\text { generic mitigating circumstances] }\end{array}$ \\
\hline $\begin{array}{l}\text { It link verb } \\
\text { [it is] }\end{array}$ & $\begin{array}{l}\text { adjective group } \\
\text { (del tutto) } \\
\text { corretto } \\
\text { [(fully) correct] }\end{array}$ & $\begin{array}{l}\text { Thing evaluated } \\
\text { concludere che nella specie la norma di legge è stata } \\
\text { [to conclude that the rule of law has been violated] }\end{array}$ \\
\hline $\begin{array}{l}\text { è } \\
\text { [it is] }\end{array}$ & $\begin{array}{l}\text { corretto } e \\
\text { legittimo } \\
\text { [correct and } \\
\text { lawful] }\end{array}$ & $\begin{array}{l}\text { fare ricorso alla verosimiglianza ed alle massime di } \\
\text { esperienza } \\
\text { [to resort to the similarity and the maxims of } \\
\text { experience] }\end{array}$ \\
\hline $\begin{array}{l}\text { Ė } \\
\text { [it is] }\end{array}$ & $\begin{array}{l}\text { corretto } \\
\text { [correct] }\end{array}$ & $\begin{array}{l}\text { utilizzare la nozione di giudicato parziale } \\
\text { [to adopt the notion of partial decision] }\end{array}$ \\
\hline
\end{tabular}

Table 14: Examples of positive evaluation in the copula $+\mathrm{ADJ}+v$-inf pattern (IT subcorpus)

In the examples provided in Tab. 14, the Supreme Court judges are (positively) evaluating how their colleague from the lower benches dealt with the case. In particular, in the first excerpt they are backing the decision of the lower-court judges ('la Corte') who ruled in favour of the defendant, granting him a 'discount' on his sentence, as it is evident from the following lines:

[9] La Corte, quindi, ha valutato la complessiva personalità dell'imputato e, proprio in considerazione di tale complessivo giudizio, ha ritenuto che fosse stata corretto concedere le attenuanti generiche solo equivalenti. La suddetta motivazione, deve ritenersi ampia, congrua e logica e, quindi, non censurabile in questa sede di legittimità, essendo stato correttamente esercitato il potere discrezionale spettante al giudice di merito in ordine al trattamento sanzionatorio.

[The Court has therefore evaluated the overall personality of the accused person and, in consideration of such overall judgement, believed it was correct to grant exclusively the equivalent generic mitigating circumstances. Such grounds should be considered as wide,

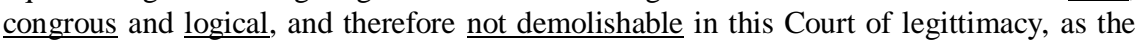
discretional power of the lower-court judge related to the entity of the penalty has been exercised correctly].

In the other three patterns, evaluation concerns legal interpretation: the lower-court judges, according to their Supreme Court colleagues, have rightly interpreted the law. If in the first excerpt the entity evaluated is explicit (the Court), in the other two patterns, as in most of the cases in the Italian subcorpus, the evaluator and the first entity to be evaluated are implicit, which could be interpreted in terms of politeness strategies. This 
is a further demonstration of the complexity ineherent in the study of evaluation in judicial discourse.

\section{Concluding remarks}

In this paper, an attempt was made to check the validity and applicability of a local grammar exemplified by two patterns the $v$-link $+A D J+$ that pattern and the $v$-link + $A D J+$ to-inf pattern to identify evaluation in judicial texts. While there is already ample evidence to suggest that these patterns are an effective way to detect evaluative adjectives (Hunston \& Sinclair 2000: 84), it was not at all certain that this claim could be equally valid for the highly specialised judicial language. Now our quantitative findings provided in Tab. 3 and 9 corroborate the observation that these patterns are indeed very often employed to express evaluation not only in US judgments but they have a relatively similar distribution in Italian texts. Our brief analysis of the patterns demonstrates that their applicability goes beyond English and it could be used as a viable unit of analysis in cross-linguistic contrastive or comparable analysis of evaluative meanings. Both English and Italian adjectives found in the patterns display striking similarities not only in terms of frequency of occurrence in the respective datasets but also with regard to the semantic property of being evaluative. While not hundred per cent of adjectives are evaluative and some manual analysis is necessary to determine the status of a given word, the proportion of evaluative adjectives is very high, ranging from $79 \%$ in the case of English adjectives to $92 \%$ for Italian adjectives in the $v$-link $+A D J+$ to-inf / copula $+A D J+v$-inf pattern. The adjectives identified in both patterns are marked by the fundamental and inherent property of carrying either favourable or unfavourable evaluation.

Apart from using the patterns to locate instances of evaluation, the analysis focused on identifying two sides of the evaluation process: evaluators, i.e. interactants expressing evaluation and interactants evaluated. Our findings provide evidence of a complex interplay between evaluative voices and a varying degree of explicitness present in the expression of evaluation. The level of explicitness in attributing evaluation to a particular interactant depends on a given adjective. In the case of the $v$-link $+A D J+$ that pattern for English data, some adjectives as in the example of correct are preceded by a nominal group in subject position. The same high degree of explicitness can be observed in the case of the $v$-link $+A D J+$ to-inf pattern / copula $+A D J+v$-inf. In both cases, these patterns enable one to detect evaluation at two levels: that of the proposition contained in the to-inf and that-clauses e.g. that many mental diseases are difficult to define, to assume that his petition by itself failed to alert the Oregon Supreme Court to the federal nature of ...) and the evaluation directed at the range of interactants to whom evaluation is attributed (e.g. the Court, respondent, dissent, etc.). However, evaluation can be less explicitly attributed. The $v$-link $+A D J+$ that pattern / copula $+A D J+$ che is frequently realised by means of the introductory or anticipatory it followed by verb in both English and Italian texts. This obviously results in an obfuscated subject and evaluation averred by the writer (evaluator). One difference between the Italian and American texts is that, in this last pattern, only US Supreme Court judges are the 
evaluators, while in Italian judgments, the appellant (through his or her legal counsel) can also express evaluation directed at a particular instance of judicial argumentation.

This brief contribution is intended as a tentative introduction offering a tantalising glimpse into the potential of using a corpus-based approach (i.e. predefined evaluative patterns searched in comparable corpus data) to ascertain the extent to which this methodology could be applied in the narrowly defined and a highly specialist genre of Supreme Court judgments. The findings obtained so far give reasons for cautious optimism. Not only is it possible to identify quickly considerable portions of evaluative language but the categories used make it possible to shed light on important interactions occurring among major interactants involved in the judicial discourse. Equally important is the potential of employing patterns as a unit of analysis in cross-lingual research. Obviously, much more work is needed, both in terms of scope and breadth, to verify the claims posited in this paper. For example, other patterns involving adjectives as well as other parts of speech should be considered. This study has been envisaged as small step towards achieving this goal.

\section{References}

Barnbrook, Geoff. 2002. Defining Language: A Local Grammar of Definition Sentences. John Benjamins Publishing Company

Bednarek, Monika (2007) Local Grammar and Register Variation: Explorations in Broadsheet and Tabloid Newspaper Discourse. ELR Journal, 1 (1).

Biber, Douglas (2006). University Language. A corpus-based study of spoken and written language. John Benjamins Publishing Company.

Chafe, Wallace and Nichols, Johanna (eds.). (1986). Evidentiality: The Linguistic Encoding of Epistemology. Norwood, NJ: Ablex.

Francis, Gill, Hunston, Susan. \& Manning, Elizabeth. (1996). Collins Cobuild Grammar Patterns 1: Verbs. London: HarperCollins.

Francis, Gill, Hunston, Susan. \& Manning, Elizabeth. (1998). Collins Cobuild Grammar Patterns 2: Nouns and Adjectives. London: HarperCollins.

Goźdź-Roszkowski, Stanisław (2007) Pattern and Meaning in Judicial Argumentation. An Exploratory Study. In: Corpora and ICT in Language Studies. Frankfurt am Main: Peter Lang, 155-166

Goźdź-Roszkowski, Stanisław \& Pontrandolfo, Gianluca. (2013). Evaluative patterns in judicial discourse: a corpus-based phraseological perspective on American and Italian criminal judgments. In: Cheng, L. (ed.) International Journal of Law, Language and Discourse: IJLLD 3.2.

http://www.ijlld.com/index.php/journal-index/2013-index/112-volume-3-issue-2-2013

Gross, Maurice (1993). Local Grammars and their Representation by Finite Automata. In (Ed) Hoey, M. Data, Description, Discourse: Papers on the English Language in Honour of John McH Sinclair. HarperCollins Publishers. pp 26-38.

Harris, Zellig Sabbettai (1991). A Theory of Language and Information: A Mathematical Approach. Oxford: Clarendon Press. 
Heffer, Chris (2007). Judgement in Court: Evaluating participants in courtroom discourse. In Kredens, K. and Goźdź-Roszkowski, S. (eds.) Language and the Law: International Outlooks. Lodz. Studies in Language series, vol. 16. Frankfurt: Peter Lang, 145-179.

Hunston, Susan. 1994. Evaluation and organisation in academic discourse. In Coulthard, M. (ed.) Advances in Written Text Analysis. London: Routledge. 191-218.

Hunston, Susan. 2004.Counting the uncountable. Problems of identifying evaluation in a text and in a corpus. In Corpora and Discourse, A. Partington, J. Morley \& L. Haarman (eds.), 157-188, Bern: Peter Lang

Hunston, Susan. 2011. Corpus Approaches to Evaluation. Phraseology and Evaluative Language. New York/London: Routledge.

Hunston, Susan \& and Francis, Gill. (2000) Pattern Grammar: A Corpus-Driven Approach to the Lexical Grammar of English. Amsterdam: John Benjamins.

Hunston, Susan \& Sinclair John. 2000. A Local Grammar of Evaluation. In: S. Hunston and G. Thompson (eds.) Evaluation in Text. Authorial Stance and the Construction of Discourse, Oxford University Press, 74-101

Hyland, Ken and Tse, Polly. 2004. Metadiscourse in academic writing: A reappraisal, In Applied Linguistics 25: 156-176.

Lehrberger John.1986. Sublanguage analysis, In: R. Grishman, R. Kittredge (eds.) Analyzing Language in Restricted Domains, Hillsdale, New Jersey: Lawrence Erlbaum Associates Publishers, 19-38

Martin, James R. and White, Peter R. 2005. The Language of Evaluation: Appraisal in English. London: Palgrave.

Mazzi, Davide. 2007. The Construction of Argumentation in Judicial Texts: Combining a Genre and Corpus Perspective. In Argumentation, 1/2007, 21-38.

Mazzi, Davide. 2010. This Argument Fails for Two Reasons... A Linguistic Analysis of Judicial Evaluation Strategies in US Supreme Court Judgements. In International Journal for the Semiotics of Law Vol. 23 No. 4, 373-385.

Montesquieu, Charles Louis de Secondat (1748) [1956]. De l'esprit des lois. Paris: Garnier.

Montesquieu, Charles Louis de Secondat (2001). The spirits of Law. Translated by Thomas Nugent. Kitchener: Batoche Books.

Ochs, Elinor. (ed.). (1989). The Pragmatic of Affect. Special Issue of Text, Vol. 9.

Palmer, Frank R. (1987). The English Verb $2^{\text {nd }}$ Edition. London: Longman.

Partington, Alan, Alison Duguid and Chrarlotte Taylor (2013). Patterns and Meanings in Discourse. Theory and practice in corpus-assisted discourse studies (CADS). John Benjamins Publishing Company

Pearson, Jennifer (1998) Terms in Context, John Benjamins Publishing Company.

Pontrandolfo, Gianluca (2013). La fraseología en las sentencias penales: un estudio contrastivo español, italiano, inglés basado en corpus. Unpublished $\mathrm{PhD}$ thesis, University of Trieste. http://www.openstarts.units.it/dspace/handle/10077/8590?mode=full

Sinclair, John. (1988). Mirror for a text. Journal of English and Foreign Languages 1: $15-44$

Taboada, Maite and Grieve, Jack. (2004). Analyzing appraisal automatically. In Proceedings of AAAI Spring Symposium on Exploring Attitude and Affect in Text. Stanford. March 2004. 158-161. 
Thompson, G. and Hunston, S. (2000). Evaluation: an introduction. In S. Hunston and G. Thompson (eds.) Evaluation in Text: Authorial Stance and the Construction of Discourse. Oxford: Oxford University Press. 1-27. 